\title{
Factors controlling pelagic barite distribution across the ocean water column: new insights from the Great Calcite Belt
}

\author{
FRANCISCA MARTINEZ-RUIZ ${ }^{1}$, ADINA PAYTAN ${ }^{2}$, \\ PHOEBE J. LAM ${ }^{2}$, MARIA TERESA GONZALEZ-MUNOOZ ${ }^{3}$, \\ FADWA JROUNDI ${ }^{4}$, MARÍA DEL MAR ABAD-ORTEGA ${ }^{5}$, \\ TRISTAN J HORNER ${ }^{6}$ AND MIRIAM KASTNER ${ }^{7}$ \\ ${ }^{1}$ Instituto Andaluz de Ciencias de la Tierra (CSIC-UGR) \\ ${ }^{2}$ University of California, Santa Cruz \\ ${ }^{3}$ University of Granada \\ ${ }^{4}$ Department of Microbiology, Faculty of Sciences, University of \\ Granada \\ ${ }^{5}$ Centro de Instrumentación Científica (CIC), University of \\ Granada \\ ${ }^{6}$ Woods Hole Oceanographic Institution \\ ${ }^{7} \mathrm{UCSD}$ \\ Presenting Author: fmruiz@ugr.es
}

Multiple lines of evidence indicate that barite precipitates at depths of intense organic matter mineralization in the mesopelagic ocean. Recent works have proved the link between barite formation and microbial activity - supported by the association of barite particles with organic matter aggregates and with extracellular polymeric substances (EPS) - and also that heterogeneous nucleation can occur even at ambient undersaturation because of organo-mineral interfacial reactions. Moreover, observations of suspended marine barite and experimental work have shown that $\mathrm{Ba}$ binds to phosphate groups on cell surfaces and within EPS leading to saturated microenvironments and nucleation sites in which $\mathrm{Ba}$ precipitation occurs. We present here a study of water column barite across the mesopelagic zone by analyzing samples collected using multiple unit large volume in-situ filtration systems in the South Atlantic and South Indian oceans to show barite distribution across the mesopelagic zone down to $1,000 \mathrm{~m}$ water depth. Paired quartz fiber filters (1-51 and $>51 \mu \mathrm{m})$ have been analyzed by scanning and high-resolution transmission electron microscopy, in particular EDX maps and selected area electron diffraction (SAED) patterns were obtained for investigating nucleation and $\mathrm{Ba}$ precipitation within particulate organic carbon (POC) aggregates. Barite abundance correlates with organic matter content and depths of extensive EPS production. In this region, diatom-rich communities produce large POC aggregates leading to intense mineralization in the mesopelagic zone. Nucleation of barite in these aggregates confirm that it forms from an initial amorphous phosphorus-rich phase that binds $\mathrm{Ba}$ and evolves to crystalline barite. These results are consistent with the close link between bacterial production and abundance of Ba-rich particulates in the water column and strongly support that biofilm matrix is crucial for $\mathrm{Ba}$ precipitation in the ocean. In general, EPS may play an important role not only for Ba bioaccumulation, but also for other element precipitation in the ocean, which has not been fully investigated 